\title{
Information Technology and Work: Threats and Opportunities
}

\author{
Pier Franco Camussone *, Alfredo Biffi*
}

\begin{abstract}
Innovation is creating robots and computers that are able to perform many tasks previously accomplished by man. The place occupied by men in the job field will shrink. The current organization and the existence of many jobs are in danger. In the article we discuss the treats and opportunities of using ICT in business and the impact on business models and on the human's job.

Through a survey on Italian business context we observe the awareness of the people directly involved in decision making and in designing future work in the firms. The consciousness of the people on the effects of the diffusion of ICT matches with the opportunities for doing business. How to find the right equilibrium between the two perspectives?
\end{abstract}

Keywords: Employment; Industry 4.0; ICT Impact; Unemployment; Robot; Artificial Intelligence; Innovation; Jobless; Global Markets

\section{The Effects of the New Technologies on the Job}

\section{The Diffusion of Computers and Robots}

Innovation is creating robots and computers that are able to perform many tasks previously accomplished by man. If Moore's Law (which sustains that every 18-24 months the cost of technology is reduced by half) remains valid even for a period of ten years in the future, this trend will be accentuated in the coming years, and more powerful and less expensive systems will compete with human resources in the field of work.

In the short term, the entry into the market of these devices will generate unemployment: many workers will be replaced by machines and will have to look for a new job. Since the diffusion of computers will be generalized and will affect all sectors of the economy, unemployment could become structural, i.e. connatural structure of with the new and more technological society.

The place occupied by men in the job field will shrink. The most manual jobs would remain, where the skill and ability necessary to accomplish them evokes the craft trades and other artistic activities. Even the most creative tasks and those difficult to program, such as managerial jobs, would remain in the charge of

\footnotetext{
* Full Professor of Organization Theory, University of Trento (pierfranco.camussone@ unitn.it)

** Associate Professor of Organization Theory, University of Insubria (alfredo.biffi@uninsubria.it)
} 
humans. Furthermore, computers will not be able to replace researchers in laboratories, scientists in scientific institutes and in general a large part of those in the techno-structure, which according to Mintzberg (1983) represents one of the five main parts of the structure of every company.

\section{The Rise of New Business Models}

Machines (with the ability to work and self-control) will replace individuals: the only doubt is to what extent this substitution will be. However, there are also other threats that are more insidious and less easy to understand.

New business models are rising (in sales, production and consumption of products and for services); they are made possible by the diffusion and intensive use of new digital technologies, which put the current organization and the existence of many jobs in danger. Let us examine some of these new models and the implications from them.

As pointed out by Evans and Gawer (Evans, Gawer 2016) in their study on new emerging models of business, a new organization of relations between the supply and demand of products and services is becoming evident. Thanks to the Internet, large corporations could be replaced by a network of medium/small firms connected to each other and synchronized through the network. The network would be responsible for the production of a final result (product or service) offered on the market (network economy).

'Subordinate work' could be replaced by the 'work on demand' carried out by freelancers who will promote themselves on the network (on demand economy). Many workers could offer their skills directly on the network, or through organizations who promote their jobs. Internet will shape the new geography of the jobs. (Grillo, Dutton, Cobo 2015).

With the Internet, many intermediaries, working between supply and demand, could disappear since they are no longer needed in a market where supply and demand meet directly.

In addition, the richness of information on the availability of resources could induce those who need it to obtain resources only for the period of time necessary to their exploitation, and then put them back on the market.

This is the model of use, rather than that of possession, which will make the production of a good, or a service more efficient and less costly. The sharing economy will emerge: an environment of shared resources used 'on demand' thanks to the meeting of supply and demand in an ideal and transparent market. In the United States, there are already many examples of this type of approach. For example, in the main cities many suppliers work on demand (on request via the Web):

- if you need to clean the house, or mount a piece of Ikea furniture, or repair a dripping tap, you can book an online intervention by experts from companies set up for this purpose such as Handy, or My Clea, or Homejoy,

- if you want to wash something at home, you can use the Washio services,

- if we forget to buy a gift and want something at the last minute, we can go to Taskrabbit, 
- if you then have the problem of delivering it immediately, you can apply to Shyp,

- if you have forgotten to replenish the kitchen, Instacart is the solution; it guarantees to buy what you need and deliver it within an hour while Blue Apron brings you the right ingredients to cook the dinner you want,

- if you want to eat at home but not cook, you have a lot of choice; in Italy there are various companies that supply home delivery, from pizza to ethnic or traditional foods,

- if you need a chef, you can contact Kitchensurfing who will send a professional to your home to prepare a meal for your guests.

Many of these services were already present in a traditional economic environment: the problem was finding who was doing them, identifying the right interlocutor, and agreeing with them on the phone. The innovation consists in the way you operate in the digital reality. You can use the Internet to select the market operators matching your needs, with the assistance of a "customer satisfaction rating system" based on the feedback from those who have already been a customer (which helps to make the market transparent). Finally, it is very easy to make an online reservation for the service.

The very interesting topic is that this way of thinking is increasing also for more professional and concept jobs. In the United States, for example:

- Medicast sends a doctor to your home

- Axiom puts a lawyer at your disposal

- Eden McCallum does the same with a business consultant (personnel research via online staffing is expected to grow by $37 \%$, according to estimations by employee placement companies)

- Appirio Topcoder can provide a coding expert; salvation in case of a delay in a project.

A freelancer economy is emerging: in the US it is estimated that workers who meet these characteristics already account for 50 million of the workforce (one in three workers). The on demand economy has changed both the labor market and the company structure as it makes the latter more efficient, but eliminates the model of the permanent job. It raises the competition between the labor suppliers and gradually reduces inefficient or unproductive staff .

According to Price Waterhouse Coopers (PWC, 2015) the sharing economy could be worth about $\$ 335$ billion in the US in 2025. The search for short-term accommodation, with AirBnb and similar setups, according to the PwC survey, could grow by $31 \%$; online staffing could increase by $37 \%$ while the car sharing services are credited with a growth of $23 \%$ per year. However, this could be an intermediate step. Hall and Krueger (Hall, Krueger 2015), who carried out research on the Uber case, while pointing out that some problems will have to be solved, conclude that this business model contributes to increasing employment; it allows many workers to integrate their incomes slightly with a second part time job, and provides customers with an alternative transport system, which is additional and not substitutive to the traditional one. The founder of Uber does not hide his goal: a totally automated service without drivers, as the self-driving car technology, 
now fully available, will become more reliable and socially accepted. It is not just a question of business profitability: the robot cars that serve one customer after another in the city, without driving around empty or clogging up the parking lots, promise to be the solution to the traffic problems that stifle the big cities.

In the new business models emerging in the market there are also nontechnological but very important aspects: the first is represented by the trust economy and the second by the economy of awareness and cooperation (caring economy). The first of these two aspects recalls what Rachel Botsman (Botsman 2010) observed: "the currency of the new economy is trust". We choose a restaurant from among those reported by TripAdvisor because we trust the opinions reported on the network by customers who have used it. The same happens when choosing a hotel through Booking.com. Even when we buy online from websites, we first check if the reviews are positive. When an operator falls in the ranking of his customers' opinions, decline is unavoidable. Trust is a difficult element to gauge as it is an ethical value that must be acquired through correct behavior and by not taking advantage of the weaknesses of its customers but rather respecting and helping those less prepared. One could say -that, for once, honesty on the net pays off.

In the caring economy neuroscience has shown that 'loving others and the environment' can motivate people in their actions, just like desire and power. The caring economy therefore aims to leverage this attitude for the common good to create a better society. Sustainability, awareness and global cooperation are the pillars of this economic model which is based on a more ethical approach to consumption and production.

We gradually come to develop a more general concept known as the collaborative economy. The economy of collaboration is a set of economic initiatives based on networks and the participation of a horizontal community (Botsman 2010) as opposed to the economic activities promoted by centralized institutions. This new business model can be seen as the sum of the following aspects:

- the sharing, which allows the continuous circulation of products and services among individuals through sharing, exchanging, trading, leasing, borrowing, etc., facilitating access, instead of ownership and thus reducing waste;

- the crowdfunding and banking from person to person which allow the movement of capital between individuals in order to finance creative projects, social purposes and start-up companies;

- the open knowledge that permits anyone to reuse freely and redistribute knowledge, such as content, data, code or drawings; this principle is the basis of the production of free software and scientific knowledge not subject to copyright.

Two final aspects that could modify the rules of many activities in the field of financial operations are the speed with which computers can perform financial transactions in the network and the possibility of planning these transactions according to models that will maximize their effectiveness. The online trading systems can open and close operations on securities in a very short time, a few seconds or less, gaining small margins which, however, become interesting when these operations are repeated at a high frequency. To define this way of working we 
use the term "scalping". This procedure, currently not sanctioned by the supervisory authorities, has increased the number of daily transactions on the stock exchange and has changed the market by making day traders prevail over long-term investors. This is a special case of the so-called real time economy (or speed economy), where time is very critical and operators interact only via computer. If this type of practice should became prevalent, stock market operators would only have the role of controllers of the market trend and give the appropriate guidelines to the computers that would then follow them.

\section{The Risk of Structural Unemployment}

Faced with such scenarios, many scholars, especially those from the technological field, are worried unlike the majority of economists who are confident about the evolution of a highly technological society invaded by computers.

Among the pessimists are:

- Erik Brynjolfsson e Andrew McAfee: The Second Machine Age; Norton, 2014;

- Frank Levy e Richard Murnane: The New Division of Labor: How Computers Are Creating the Next Job Market, Princeton University Press, 2005;

- Jeremy Rifkin: The End of Work: The Decline of the Global Labor Force and the Dawn of the Post-Market Era, Putnam Publishing Group, 1995, ISBN 0-87477-779-8; and: The Zero Marginal Cost Society: The internet of things, the collaborative commons, and the eclipse of capitalism, Palgrave Macmillan, 2014, ISBN 978-1-137-27846-3,

who believe that the impact of high computerization on society will be more traumatic than the first industrial revolution of the late eighteenth century when the introduction of the steam engine drastically changed the organizational structure of the textile factories in England.

An analytical study on the potential impact of the introduction of computers and robots in the American labor market was done by Frey and Osborne (Frey, Osborne 2013) who examined about 700 different jobs from the classification of the US Department of Labor. For each job, the possibility that some of the activities would be automated, depending on the repetitiveness and predictability of the actions to be taken, was analyzed.

The results show that out of 138 million workers (91\% of the USA labor force) $47 \%$ of the jobs (i.e. 65 million) would be seriously affected by the introduction of PCs and robots. This means that in the United States, the work of almost one in two people will be affected by a partial, or total, replacement by machines. The research has also indicated that the economic sectors most influenced by this phenomenon would be logistics and transport, as well as the production sector in general and delivery of repetitive services. The functional areas, where the phenomenon will be more evident, would be back office and clerical tasks.

In light of these authors, we should prepare to deal with social crises and periods of workforce retraining during unemployment. From their reflections, the fear that in a long range perspective the temporary joblessness would not be reabsorbed and could be converted into structural unemployment arises. Many classical economists, however, believe that the economic system will find its equilibrium in the medium- 
long term and reabsorb the excess workforce. This confident attitude is supported by past experience. Every innovation, especially if very pervasive and felt deeply, has always created temporary unemployment, but its effects (reduction of production costs and lower prices) have always generated an increase in demand. This growth, in turn, led to an increase in production which then led to the reabsorption of unemployed workers or to the generation of new opportunities for people looking for jobs. In the past, the workers made available by the use of innovations, and not absorbed by the growth in demand, were directed towards other sectors thus creating new business areas. The automation of assembly lines, or manufacturing workshops, released a labor force which developed the service sector. We should not overestimate our fears as the natural creative force of mankind will be able to identify new opportunities and develop new unimaginable business sectors. In pure speculative spirit, these scholars point to the field of ecology and land recovery, the treatment of senior citizens and the disabled, the improvement of health care, and the enhancement of the artistic heritage as possible examples of new sectors to develop.

\section{Classic Paradigms and Some Doubts}

Keynes in his famous London conference in 1930 introduced the suggestion that his grandchildren would not "work anymore". However, faced with this undoubted advantage (no longer having to work for survival reasons) he mentioned some surprising consequences "[... because] we have been expressly evolved by nature - with all our impulses and deepest instincts - for the purpose of solving the economic problem. If the economic problem is solved, mankind will be deprived of its traditional purpose. And I think with dread of the readjustment of the habits and instincts of the ordinary man, bred into him for countless generations, which he may be asked to discard within a few decades».

In general, however, the prevailing thinking among current economists is to look confidently at the spread of computer innovations which will not only create a temporary joblessness, but open up new areas of needs.

Nonetheless, among economists there are less confident voices about the ability of markets to reabsorb the joblessness generated by technological innovation (Ford M. 2015) and refer to the famous metaphor of the Wassily Leontiev horses (Leontiev W. 1983), according to which men risk the demise of horses in the American economy when they were replaced by the internal combustion engine. This reflection, known as the metaphor of the horses and the workers, starts from a consideration on the development of the equine population in the United States, over the last two centuries, and ends with a prophecy. The horse was one of the critical production factors for the development of the American economy in the 19th century. The equine population, with the increase in the demand of people and goods mobility between 1840 and 1900, grew six fold (up to 21 million, compared with 75 million people). The horse was the driving force on which to rely in the field of transport, agriculture, mining exploitation, and industrial logistics, 
throughout the 19th century. But the internal combustion engine led to its replacement, even if the demand for mobility continued to grow. When engines were added to cars in the city and tractors in the countryside, horses became largely irrelevant/redundant. In 1960, there were no more than 3 million horses throughout the United States, and few were used for work. Once the correct technology was established, the fate of the horse as a work force, was marked.

The same fate could belong to the human labor force because of computers; for Leontiev: "... few workers will remain, only those able to conceive new products and services: the role of men in production will be reduced, like that of horses ..».

How can you object to this negative prophecy? The simplest and most intuitive answer is "fortunately human beings are not horses" and they can act to avoid economic irrelevance and will certainly do everything to succeed.

\section{The future of work and the academic debate}

At this point it is helpful to provide a summary of the main opinions that confront the academic debate about the effects of computer technology on jobs. The different positions can be traced back to four schools of thought (figure 1).

Figure. 1. The Future of Work in the Academic Debate

\section{Four possible future scenarios}

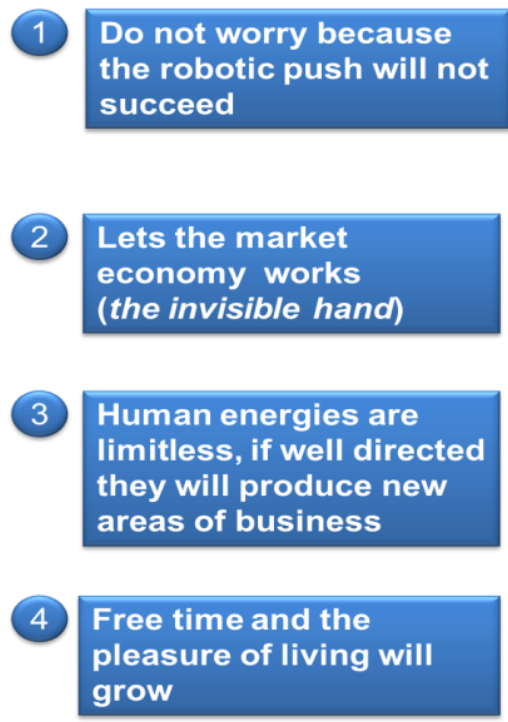

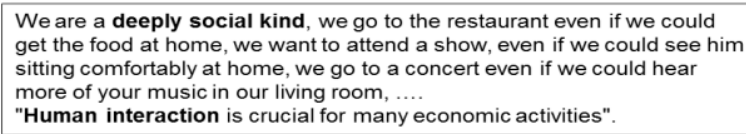

We are a deeply social kind, we go to the restaurant even if we could get the food at home, we want to attend a show, even if we could see him sitting comfortably at home, we go to a concert even if we could hear

"Human interaction is crucial for many economic activities"

Economic society has remedy in itself, when a sector does not attract workers, they look for work elsewhere, and new sectors are developed.

Human creativity could be directed towards the fight against diseases environmental rehabilitation, artistic production, handicrafts, etc. reserved to the "negotium" and give more time to the "otium" (as the ancient Romans said)

The first argues that we are worrying too much; the reality will not be as dark as the technologists paint it (Colvin 2015). The natural need for social relations will stop the spread of robots and computers in the service society.

The second school is represented by those who put great confidence in the rules of the free market by following the thought of Adam Smith, Vilfredo Pareto and the liberal 
scholars. Society has the inbred remedies; when a sector does not attract workers, they seek work elsewhere and consequently develop new unexpected sectors. Even in this case, the economic mechanisms that regulate the market economy (the invisible hand) would overcome the momentary difficulties. The third current of thought is made up of those who have confidence in the ability of human survival in the face of any difficulty; human energies are limitless and if properly addressed, will produce new business areas. The spirit of initiative will do miracles, or rather will take its natural course, producing surprising results. Human creativity should be addressed and guided (this is the difference from the previous school) towards new long-term goals for mankind, such as the fight against disease, restoring the environment, artistic production, and the creation of cultural events.

Finally there are those who are fascinated by the Keynes prophecy. They abandon themselves to the most optimistic predictions about the future activity of mankind. We are at the end of the time the man should work out of need. Why insist on working if others do it for us; it is better to reduce the time spent on «Negotium» and give more time to «Otium» (as the ancient Romans said). Let us take advantage of innovation.

Those who are interested in exploring the contributions to this debate will find a table in the last part of the paper (Analysis of contributions on the future of work).

\section{Jobs and Welfare}

The welfare of the current society is strongly influenced by the kind and level of consumption which its members can afford (consumer society). If the spending capacity of families shrank, the level of well-being of our society would retract and many of the social achievements obtained would be at risk (health, education, social security.).

Therefore, for the development of the future society, we must avoid any kind of recession in the level of material and cultural well-being and think about how to manage these phenomena. The problem has two temporal aspects: in the short term many people should be retrained because their role would be taken over by robots and computers, and they should find another occupation. This contingent unemployment derives from the diffusion of innovations and has always occurred. We must manage the movement of workers to other sectors, potentially able to absorb the excess labor force. This would require appropriate welfare tools which must be activated for the transitional period required by the social reorganization.

However, if the shortage of work activities was persistent in the long-term, we must think of solutions to tackle the under-employment or structural unemployment. To avoid the risk of widespread social problems, several alternatives are suggested. The most popular are: the basic income and the negative tax. The first proposal tends to ensure a basic income for all workers which allows an adequate standard of living regardless of the activity carried out. The second involves a system of taxation that can become negative for lower incomes (i.e. it returns money to citizens) to allow everyone to maintain an adequate standard of living. This system would respect the ability and ambition of those who want to engage in more profitable activities by ensuring everyone a minimum level of income.

The basic income is an idea which had already been proposed a long time ago by political activists like Thomas Paine who in 1797 suggested paying compensation to those who had had the bad luck to be born in social disadvantaged contexts. A 
resumption of this proposal lies in the writings of Bertrand Russell and in the speeches of Martin Luther King aimed at fighting poverty.

As Brynjolfson and McAfee recall, many modern economists in both the liberal area - James Tobin, Paul Samuelson and Kenneth Galbraith - and conservative field - Milton Friedman and Frederic Hayek - have proposed, in more or less similar ways, a practice of minimum income guarantee. Even in 1968, more than 1200 economists signed a letter to the United States Congress supporting the transformation of these hypotheses into a law (Sreenivasan J. 2009).

The Nobel Prize in Economics, Milton Friedman, also put forward a proposal that is the most practical alternative to guaranteed basic income. It is a system of taxation that can become negative for lower incomes (i.e. returns money to citizens). For example, if it is accepted that $\$ 20.000$ a year is the minimum income to allow citizens an adequate standard of living, then the tax system should impose taxes only on the part exceeding this amount. Not only that, it should also contribute to the achievement of this threshold if the income is lower.

Hence the expression "negative taxation". This system would respect the capacity and willingness of citizens to engage in profitable activities, guaranteeing everyone a minimum income level.

Those in favor of such an approach go even further by suggesting the use of the tax system to drive economic development more strongly. Already, for example, in Italy the tax burden on smoking has been raised but, on the other hand, the installation of solar panels has been encouraged. The State could reduce the concentration of wealth, with a higher burden on wider income and assets, in order to create a store for the redistribution of the new wealth produced to those whose work will no longer be needed.

Or the State could encourage not the construction of robots that completely replace the human work but the creation of collaborative systems that help people to improve their work performance.

Another area to support and strengthen is the one that is designated with the notfor-profit expression. Currently this sector is strongly supported by volunteers, but in the future, with appropriate economic policies, those who work in this area (often involving disadvantages or social difficulty) should receive a salary, thus creating remunerated jobs.

The government could also reward the creation of jobs that can only be occupied by people. Tax incentives could be found for those who directly employ human resources, for example in agriculture, handicrafts and services to people. But there are also other economic sectors in which the wealth produced by automation and computers could be invested: for example, cleaning and environmental recovery, the enhancement of artistic and cultural assets and so on. A stimulus in this sense comes from a neologism proposed by Brynjolfsson and McAfee: "workfare". An objective for the development of the future society should not only be welfare (i.e. 
well-being), but also workfare, i.e. a social system that ensures the work of as many citizens as possible and whose welfare should then be guaranteed by other social and fiscal instruments.

\section{The Need for New Skills}

To face the threats arising from the spread of computers and robots in all economic activities, we must prepare people culturally in order to avoid succumbing to such a society. First we need to rethink the educational system. What must we teach citizens to give them the best opportunity to live in this new social system where the repetitive and programmable work will be will be carried out by machines? We should probably prepare a different education system from the one currently in place. If we want people to make a contribution to social development, they will have to be able to plan and design the machines, or at least to use them as best as possible. We will probably have to reconsider the subjects taught and introduce new ones, like computer programming logic, or man-machine relationship. Another founding pillar of the new educational system could be knowledge management. We should learn to extract knowledge from the data the machines acquire and store and we should also learn to reproduce and disseminate better knowledge through computers.

Unthinkable perspectives could open up for scholars and researchers who will have easy access to the enormous capital of knowledge that has been accumulated over time and which is made available to everyone, at very low costs, by new technologies.

Perhaps the more surprising and radical changes could be the transition from a mainly notional educational system to one that develops the creativity and potential of students.

Only by emphasizing this aspect of the character of the learners can students then become creative and original, and able to continue the development of a world where most of the trivial work will be performed by machines.

\section{The Level of Awareness in Italy: an Empirical Survey}

As we have seen, the conceptual framework on the future of work proposes different perspectives for the quality of people's lives and the development of professional roles. But how many people in the Italy are aware of the impact of technology on the risk of unemployment and on welfare? An empirical part of the research project has explored this topic and some results are synthetically presented here. We probed a sample of experts on the matter and opinion leaders (14), startuppers (62), general managers (243), human resources managers (115), students and young graduates (300) - in total 734 people. The results show those who are already involved in work and in business are fully aware of the strong negative impact of technology on work, while students, in particular, are divided between those who think the work will survive and those who think it will collapse.

The research contains some details about various questions: what work will be mainly "impacted" (only physical or also intellectual work), and how much? How long will it take to see the effects of the impact of the new technology? What are the technologies that will produce the most effects, and how many people really 
understand these technologies?. What are the effects on some specific organizational roles such as managers and human resources officers who will be the responsible for managing the impact and developing solutions for the future of people without work?

The research used interviews to collect the opinions of experts and opinion leaders, and customized questionnaires to fill in for all the other participants. We decided not to interview politicians in order to obtain a picture free from any dogmatic pressure to offer to politicians a framework to think about. Even if the research is mainly qualitative, some results are so clear and interesting that we thought it useful to present them graphically.

\section{The ICT Effects on Human Work in Enterprises}

Enterprises will use ICT to innovate products and services and to improve processes: this could modify business models with strong impacts on work organization and on the use of men or machines. Technologies could destroy physical and conceptual work in industrial plants but also in offices.

All our participants are convinced that repetitive work (both physical and intellectual) will be mainly destroyed but are less unanimous about conceptual jobs (fig. 2). In detail, start-uppers think that ICT could not substitute human intelligence in all the types of work $(54,8 \%)$. Students are more optimists and are split into those who think that technology will destroy work (48\%) and those who do not (52\%). It seems that those already in business and have work experience are more afraid about what will happen while who have "to discover work" have more trust in technology as tool for producing work. They also think that we will be able to manage the transition. This is confirmed by the fact that among the few who think work will increase, $82 \%$ are sure that ICT will create more work. In general, little more than $50 \%$ of the respondents think the unemployment will be structural and permanent (fig. 3).

In summary, even if optimistic visions for human labor can be found in international studies, the opinion of our participants seems to be more pessimistic about the impact of ICT on human work in an enterprise. This feeling could have important implications on economic and social life.

Figure 2. Will Computers and Robots Replace Human Labor?

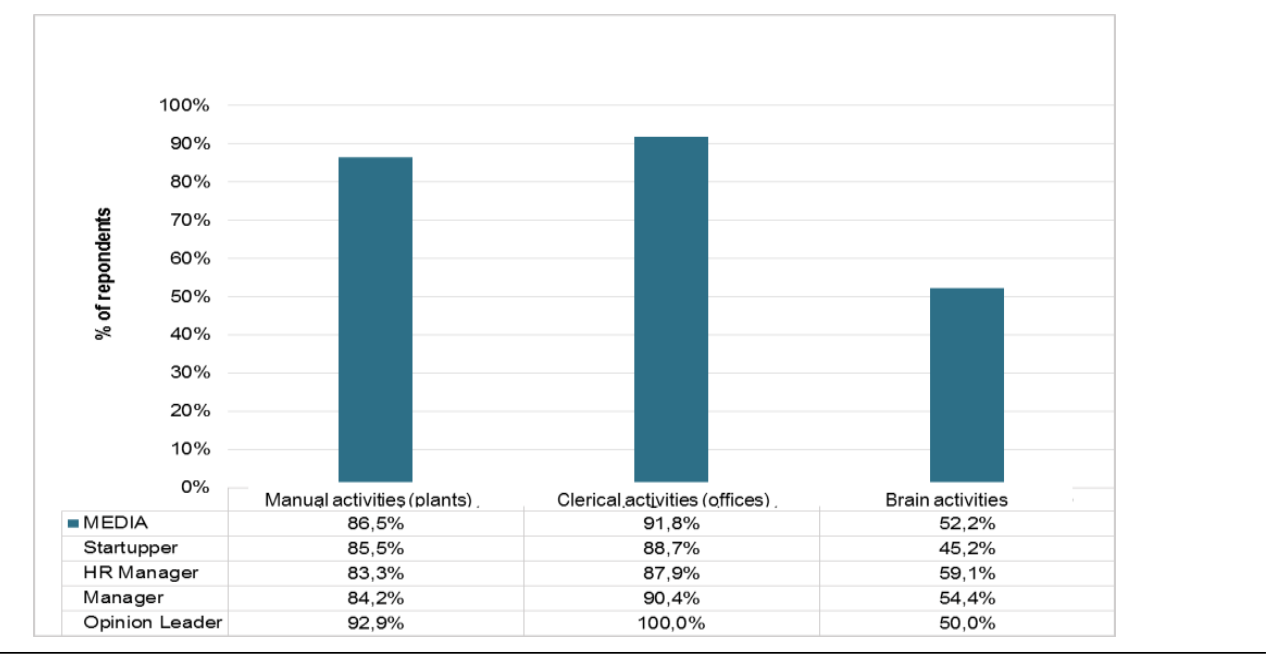


Figure 3. Can We Expect Structural Unemployment or Will We Find Solutions or Some Way Out.

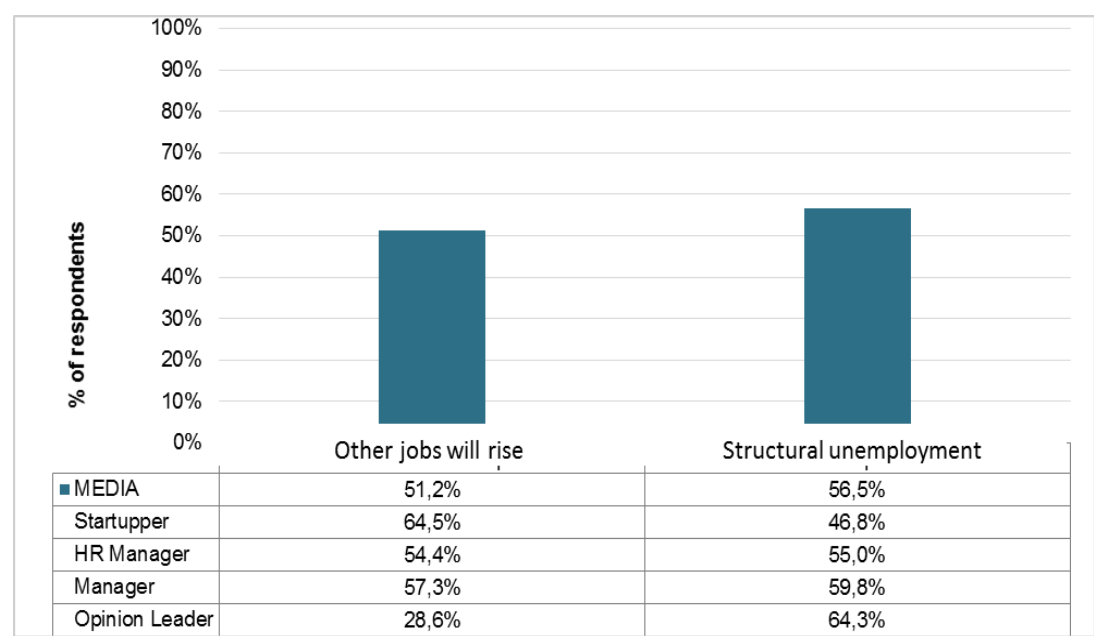

\section{Economic and Social Effects}

Interestingly, thanks to ICT innovation, productivity will growth even if less people work. GDP should also growth and wealth will augment exponentially but according to our experts and opinion leaders, the generated wealth will be concentrated in the hands of people involved in high-tech sectors as designers, managers and technology experts. (fig. 4).

Fig. 4: Impact of ICT on GDP (With Fewer Employees)

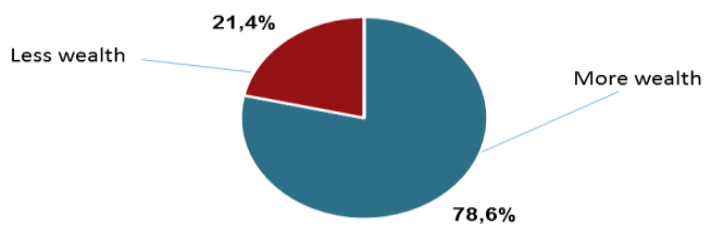

Moreover, compared to the past, the replacement of skills will be more evident (61\% of our interviewees agree) and, above all, accelerated.

The new competences required are heavily based on ICT and everybody will have to master the use of ICT devices. This valuation is fundamental for enterprises: the mismatch between the demand and supply of work, already high today, could increase dramatically if firms cannot find the right people to do business. It is also important for people to develop the right competences otherwise they risk being pushed out of the job marketplace. 
On the other hand, the opportunity to improve the quality of life is a good possibility (fig. 5). Machines and robots that work in our place could make us free to dedicate ourselves to hobbies, personal passions or the care of others, and other pleasant aspects of life. We would certainly have more free time, but our respondents are not sure if this will mean a better quality life. The shortage of work, which for many is their main reason for living, could cause them to fall into depression. Living standards could be lower than today. Many people could prefer to be managed rather than be proactive themselves (with a lot of free time to spend)

Figure 5. ICT Impact on Quality Life

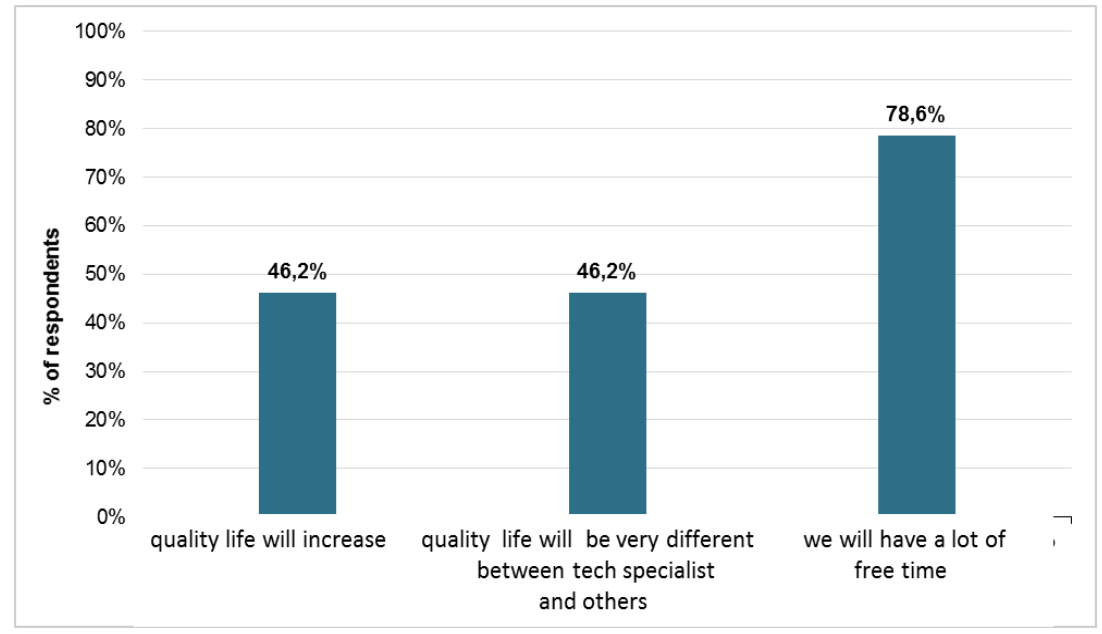

It appears that, in the perception of the Italian sample, the social impact of ICT diffusion will maintain the existing differences and inequality.

According to the respondents, we will have the maximum degree of all these effects to deal with in the next five-fifteen years: we will have to find a social and economic solution and to implement it in no more than ten years.

\section{Organizational Impacts on Enterprises}

Several elements in the structure of the future enterprise are dependent on the vision of ICT use in the firm. With an intensive use of ICT, and intense substitution of people by computers:

- $\quad$ firms will be organized in an ever flatter organizational model, with high empowerment of the few people left;

- $\quad$ firms (with less people) will have less need of bosses but managers will have to improve processes and use technology smartly; managerial competences will be more diffused than at present and some managerial skills will also be in the role profile of a tech specialist.

Technology should be used for more efficient company organization and the ICT level of knowledge will became a fundamental criteria when hiring (fig. 6 in details). 
Figure 6. The Relevance of ICT Knowledge When Hiring

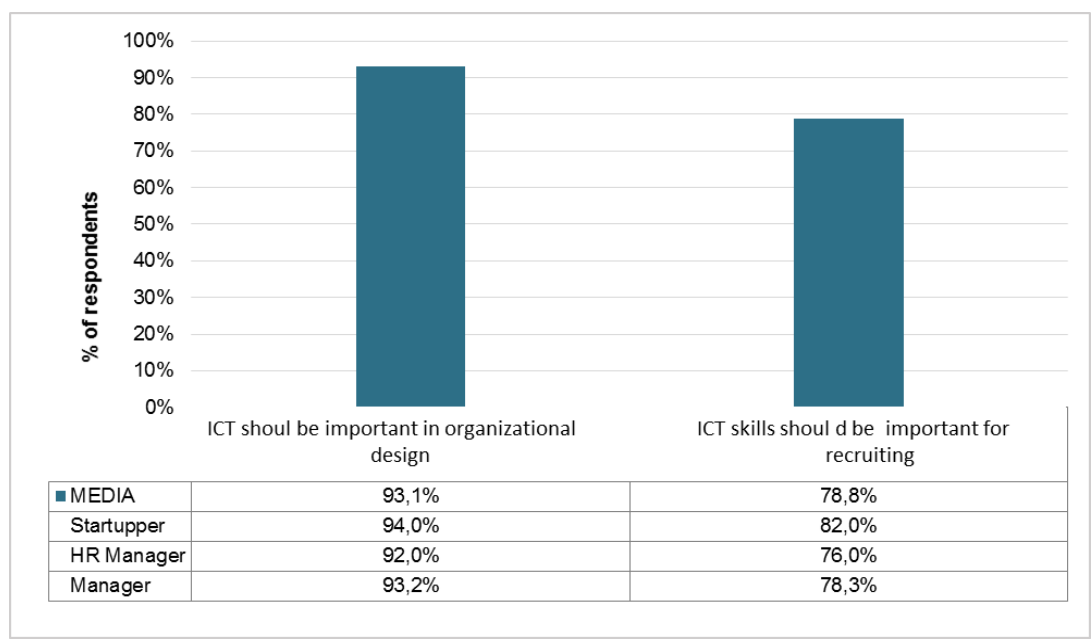

\section{Students' and Graduates' Vision}

An important topic in our research was the question on the attractiveness of ICT for the young people ready to enter a professional life. Are the technology-based and technology-oriented sectors really an interesting perspective for students and graduates looking for work?

We asked them to make a first and a second choice if they were contacted by wellknown companies from different business sectors.

The companies were selected as representatives of business sectors coherent with the course attended by students (about 65\% economic and social science, 35\% technical and scientific) This was also to understand how much a study course could influence their choice.

We did not found a clear orientation towards firms operating in high technology sectors. Only $11 \%$ of the respondents declared a desire to work in this type of enterprise, while $25 \%$ wanted to work in sectors coherent with the courses of study followed (fig. 7).

This result is remarkable, considering the problem of mismatching between demand and supply of work. 
Figure 7. Students and Graduates: Desire for First Job (Which Sector Would Students/Graduates Choose to Work in?)

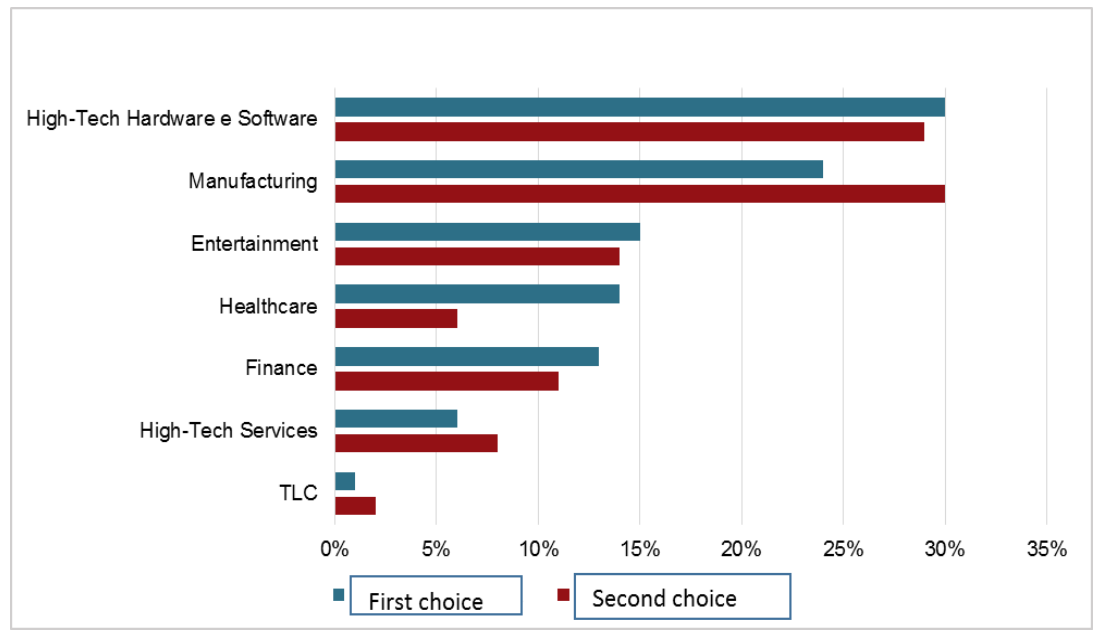

\section{Perspectives from the Italian Sample}

How can the problem of maintaining the level of employment and using the ICT based innovation in the business be dealt with? ICT could destroy work but it will certainly drastically change the way we will work.

Asking our participants about the various aspects of the problem was the framework for the solutions they suggested. For example, expert and opinion leaders said:

- we will study original forms to distribute the wealth produced by the automation (92\% of those interviewed) also to the people who will work less to allow them to maintain their existing level of spending;

- if the redistribution of wealth to find an acceptable equilibrium of quality life between the employed and unemployed is not enough, we have to find a solution by choosing from ( $86 \%)$ :

$\checkmark$ stimulating the manual work in sectors where the use of ICT (low automated sectors) is difficult;

$\checkmark \quad$ finding new additional businesses to create new jobs, even with use of new technologies;

$\checkmark$ re-launching and strengthening economic domains under estimated at present (i.e. arts and handicrafts).

Obviously, the main decision should be political but according to the managers and the human resources officers in our sample, enterprises should also be involved and must participate in the defense of jobs levels (73\% of those interviewed).

The final suggestion, from everyone, is to rethink the educational system to prepare for new needs: we should foster all the ICT topics, knowledge and innovation management, men-machine interaction, privacy and security but also 
invest in soft skills to allow people to manage the ever-increasing relationship based work framework.

\section{Emerging Issues}

The picture that emerges shows very clear opinions on some questions and less notable ones on others. For example, if all agree on the gradual substitution of human work by machines, even in the high level conceptual jobs, not all agree about the impact on managerial jobs. On the basis that there will be less people to manage and that organizations will be flatter, some suggest that we will need less managers in the future. However, regarding the fact that all the internal and external processes will change and become more complex, some state that we will need more managers than now (probably more technical).

The responsibility for finding solutions to work scarcity will also fall to companies and not only to politicians and economists: a form of social responsibility will flourish inside the enterprises. One solution emerges as the most proposed: to focus on education at all levels in order to prepare people to deal with a fragmented work market where we will probably have one person for a single task and job. We need to specify what education means from the point of view of the content, the educational process and above all the quality of the 'final result' (what type/types of educated people).

The final results of the research can be summarized as follows:

- the degree of awareness of the problems is very high, and even students and graduated who are not working yet seem to perceive it;

- those who work are more convinced about the decline in work over the next two decades and that we do not have much time to solve the issue;

- technologies are not perceived as a tool to decisively improve our quality of life, but only as a productive factor useful for business development. Even when ICT relieves physical or intellectual effort, more free time risks becoming another element of the problem: how to spend this free time. The solutions are very fragmented and individual (but this could be really the end of the need to work for mankind);

- two considerations on how to act. It is impossible to stop the technological evolution, which has always been a human opportunity for development. We have to act by shaping people with competences aligned with the technological work and with the imagination to create new opportunity for new jobs. 


\section{Literature Review}

\begin{tabular}{|c|c|c|c|}
\hline $\begin{array}{l}\text { In-depth Analysis of } \\
\text { Contributions on the } \\
\text { Future of WorkSource }\end{array}$ & Focused on & Main evidence & Interpretation \\
\hline $\begin{array}{l}\text { C.B. Frey, M. Osborne, } \\
\text { The Future of } \\
\text { Employment (Working } \\
\text { paper, Oxford Martin } \\
\text { School, 2013), basic } \\
\text { paper }\end{array}$ & \begin{tabular}{l}
\multicolumn{1}{c}{ Work } \\
destruction rate \\
calculated on 702 \\
jobs in USA
\end{tabular} & $\begin{array}{l}\text { Within } 10 \text { years } 47 \% \\
\text { of the workforce in the } \\
\text { USA is at a risk of } \\
\text { strong negative impact. } \\
\text { An in-depth analysis by } \\
\text { the Oxford Martin } \\
\text { Center establishes this } \\
\text { value for Italy around } \\
56 \% \text {. }\end{array}$ & Possible destruction impact \\
\hline $\begin{array}{l}\text { E. Brynjolfsson, A. } \\
\text { McAfee, The Second } \\
\text { Machine Age (New York- } \\
\text { London, W.W. Norton) }\end{array}$ & $\begin{array}{l}\text { What will } \\
\text { happen and how } \\
\text { we will behave. }\end{array}$ & $\begin{array}{l}\text { It will be destruction, } \\
\text { but human beings will } \\
\text { shape a new society } \\
\text { with a low intensity of } \\
\text { human work. }\end{array}$ & Challenging based vision \\
\hline $\begin{array}{l}\text { World Economic } \\
\text { Forum, The Future of the } \\
\text { Jobs Report (January } \\
\text { 2016) }\end{array}$ & $\begin{array}{l}\quad \text { Strong } \\
\text { quantitative } \\
\text { impact; } \\
\text { evaluation on } \\
\text { action education } \\
\text { based as solution }\end{array}$ & $\begin{array}{l}\text { Loss of seven million } \\
\text { jobs, only in a part } \\
\text { balanced by two million } \\
\text { new ones. Interviews } \\
\text { with Human Resource } \\
\text { Managers: only } 52 \% \text { are } \\
\text { sure that their firms are } \\
\text { prepared for this } \\
\text { discontinuity. }\end{array}$ & Certain destruction impact \\
\hline $\begin{array}{l}\text { Deloitte, Technology \& } \\
\text { People. The Great Job- } \\
\text { creating Machine (August } \\
\text { 2015) }\end{array}$ & $\begin{array}{l}\quad \text { General } \\
\text { analysis based on } \\
\text { research realized } \\
\text { with a sample of } \\
\text { ICT managers }\end{array}$ & \begin{tabular}{l}
\multicolumn{1}{c}{$48 \%$ of experts in } \\
technologies think that \\
work will disappear for \\
both specialized and \\
non-specialized \\
workers.
\end{tabular} & Neutral \\
\hline $\begin{array}{l}\text { McKinsey Quarterly, } \\
\text { Where Machines Could } \\
\text { Replace Humans-and } \\
\text { Where They Can't (Yet) } \\
\text { (July 2016) }\end{array}$ & \begin{tabular}{l}
\multicolumn{1}{c}{ Analysis of } \\
2000 different \\
activities (for 800 \\
jobs)
\end{tabular} & $\begin{array}{l}\text { Almost half of the } \\
\text { present jobs will be } \\
\text { impacted and could be } \\
\text { automatized within } \\
2050 \text {; almost } 60 \% \text { of } \\
\text { the existing jobs have }\end{array}$ & Possible destruction impact \\
\hline $\begin{array}{l}\text { McKinsey Global } \\
\text { Institute, A Future That } \\
\text { Works: Automation, } \\
\text { Employment and } \\
\text { Productivity (January } \\
\text { 2017) }\end{array}$ & $\begin{array}{l}\text { In depth } \\
\text { analysis of the } \\
\text { previous research }\end{array}$ & $\begin{array}{l}30 \% \text { of activities that } \\
\text { could be automatized. } \\
\text { Some business sectors } \\
\text { will have a prospective } \\
\text { of ever-increasing } \\
\text { automation (i.e. finance, } \\
\text { healthcare). }\end{array}$ & $\begin{array}{l}\text { Destruction impact } \\
\text { confirmed. Some possibilities } \\
\text { for partial recovery }\end{array}$ \\
\hline $\begin{array}{l}\text { McKinsey Global } \\
\text { Institute, Jobs lost, jobs } \\
\text { gained: workforce } \\
\text { transitions in a time of } \\
\text { automation, (December } \\
2017 \text { b) }\end{array}$ & $\begin{array}{l}\text { Continuation of } \\
\text { the research }\end{array}$ & $\begin{array}{l}\text { Thin specification: } \\
\text { technology will destroy } \\
\text { jobs not work. Some } \\
\text { proposals to deal with } \\
\text { the ....? }\end{array}$ & \\
\hline $\begin{array}{l}\text { BCG, Man and } \\
\text { Machine in Industry } 4.0 \\
\text { (September 2015) }\end{array}$ & $\begin{array}{l}\text { In depth, where } \\
\text { the work changes, } \\
\text { analyzing the } \\
\text { detailed execution } \\
\text { of manufacturing } \\
\text { processes in some } \\
\text { German } \\
\text { enterprises. }\end{array}$ & $\begin{array}{l}\text { IT and data science } \\
\text { will compensate for the } \\
\text { job losses within } 2025 \text {, } \\
\text { with about } 350,000 \\
\text { more workplaces in } \\
\text { Germany. }\end{array}$ & Positive vision, some hope \\
\hline
\end{tabular}




\begin{tabular}{|c|c|c|c|}
\hline $\begin{array}{l}\text { USA: Bureau of Labor } \\
\text { Statistic BLS, } \\
\text { Employment Projections } \\
\text { 2014-2024 (December } \\
\text { 2015) }\end{array}$ & $\begin{array}{l}\quad \text { Quantitative } \\
\text { estimate on how } \\
\text { many workplaces } \\
\text { will be generated } \\
\text { (no one } \\
\text { consideration for } \\
\text { the role of } \\
\text { technology) }\end{array}$ & $\begin{array}{l}\text { Growth of } 9,8 \\
\text { millions workplace } \\
\text { within } 2024(6,5 \% \\
\text { more). }\end{array}$ & $\begin{array}{l}\text { Positive vision (but does } \\
\text { not explain what the } \\
\text { technology effects will bein } \\
\text { the quantitative model) }\end{array}$ \\
\hline $\begin{array}{l}\text { KPMG, U.S. } \\
\text { Technology Industry CEO } \\
\text { Outlook (September } \\
\text { 2016) }\end{array}$ & $\begin{array}{l}\text { Survey of } 138 \\
\text { CEOs in tech } \\
\text { enterprises }\end{array}$ & $\begin{array}{l}5 \% \text { of the workforce } \\
\text { will be impacted, but } \\
\text { almost } 6 \% \text { more work } \\
\text { will be created. }\end{array}$ & $\begin{array}{l}\text { Positive vision, some hope } \\
\text { (but strictly in the domain of } \\
\text { ICT) }\end{array}$ \\
\hline $\begin{array}{l}\text { UK Commission for } \\
\text { Employment and Skills, } \\
\text { Working Future 2014- } \\
2024 \text { (April 2016) }\end{array}$ & \begin{tabular}{l}
\multicolumn{1}{c}{ Analysis of 75} \\
industries and 369 \\
jobs from $2014-$ \\
2024
\end{tabular} & $\begin{array}{l}\text { In ten years } 1.8 \\
\text { million workplaces will } \\
\text { be created; there will be } \\
\text { loss of workplaces in s } \\
\text { intermediate and routine } \\
\text { type activities but the } \\
\text { loss in not quantified. }\end{array}$ & $\begin{array}{l}\text { Positive but not completed } \\
\text { in the quantitative analysis. } \\
\text { Data only on the United } \\
\text { Kingdom }\end{array}$ \\
\hline $\begin{array}{l}\text { Executive Office of the } \\
\text { President, Artificial } \\
\text { Intelligence, Automation } \\
\text { and The Economy } \\
\text { (December 2016) }\end{array}$ & $\begin{array}{l}\text { Qualitative } \\
\text { analysis }\end{array}$ & $\begin{array}{l}\text { No clear position } \\
\text { about the impacts. The } \\
\text { right political choices } \\
\text { could result in positive } \\
\text { effects and eventual } \\
\text { negative impacts. }\end{array}$ & $\begin{array}{l}\text { Positive, but under the } \\
\text { condition to mediate on the } \\
\text { development logics. Some } \\
\text { hope. }\end{array}$ \\
\hline
\end{tabular}

\section{Bibliography}

Ackerman, R.W. (1973). How Companies Respond to Social Demands, Harvard Business Review, $51(4), 88-98$.

Arrigo, E. (2003). Corporate Responsibility in Scarcity Economy. The Olivetti Case, Symphonya. Emerging Issues in Management (symphonya.unimib.it), (1), 114-134. http://dx.doi.org/10.4468/2003.1.10arrigo

Bakos, Y. (2001). The Emerging Landscape for Retail E-Commerce, Journal of Economic Perspectives, 15 (1), 69-80. doi: $10.1257 /$ jep. 15.1 .69

Bowen, H.R. (1953). Social Responsibilities of the Businessman, New York: Harper\&Row.

Brondoni, S.M., \& Mosca, F. (2017). Ouverture de 'Integrated Corporate Social Responsibility', Symphonya. Emerging Issues in Management (symphonya.unimib.it), (1), 1-6. http://dx.doi.org/10.4468/2017.1.01ouverture 1

Brondoni, S.M. (2012). Innovation and Imitation: Corporate Strategies for Global Competition, Symphonya. Emerging Issues in Management (symphonya.unimib.it), (1), 10-24. http://dx.doi.org/10.4468/2012.1.02brondoni

Brondoni, S.M. (2008). Market-Driven Management, Competitive Space and Global Networks, Symphonya. Emerging Issues in Management (symphonya.unimib.it), (1), 14-27. http://dx.doi.org/10.4468/2008.1.02brondoni

Carroll, A.B. (2000). Ethical Challenges for Business in the New Millennium: Corporate Social Responsibility and Models of Management Morality, Business Ethics Quarterly, 10 (1), 33-42. https://doi.org/10.2307/3857692

Carroll, A.B. (1999). Corporate Social Responsibility: Evolution of a Definitional Construct, Business and Society, 38 (3), 268-295. https://doi.org/10.1177\%2F000765039903800303

Carroll, A.B. (1998). The Four Faces of Corporate Citizenship. Business and Society Review, 100$101(1), 1-7$. https://doi.org/10.1111/0045-3609.00008

Carroll, A.B. (1991). The Pyramid of Corporate Social Responsibility: Toward the Moral Management of Organizational Stakeholders, Business Horizon, 34 (4), 39-48. https://doi.org/10.1016/0007-6813(91)90005-G 
Carroll, A.B. (1979). A Three-Dimensional Conceptual Model of Corporate Social Performance, Academy of Management Review, 4 (4), 497-505. doi: $10.2307 / 257850$

Conad. (2015). Conad Annual Report.

Crane, A., Matten, D., \& Spence, L.J. (eds.) (2008). Corporate Social Responsibility: Readings and Cases in Global Context, London: Routledge.

Dahlsrud A. (2008), How Corporate Social Responsibility is Defined: an Analysis of 37 Definitions, Corporate Social Responsibility and Environmental Management, 15 (1), 1-13. https://doi.org/10.1002/csr.132

Davis, K. (1975). Five Propositions for Social Responsibility, Business Horizons, 18 (3), 19-24.

Davis, K. (1967). Understanding the Social Responsibility Puzzle: What does the Businessman Owe to Society?, Business Horizons, 10 (4), 45-50.

Davis, K., \& Blomstrom, R.L. (1966). Business and its Environment, New York: McGraw-Hill.

Deloitte. (2017). Global Power of Retailing. The Art and Science of Customers.

Eilbirt, H., \& Parket, I.R. (1973). The Current Status of Corporate Social Responsibility, Business Horizons, 16 (4), 5-14. https://doi.org/10.1016/0007-6813(73)90043-8

Elkington, J. (1997). Cannibals with Forks: The Triple Bottom Line of 21st Century Business, Oxford: Capstone Publishing Ltd.

Frederick, W.C. (1998). Moving to CSR4. What to Pack for the Trip, Business \& Society, 37 (1), 4059.

Frederick, W.C. (1994). From CSR1 to CSR2: the Maturing of Business and Society Thought, Business \& Society, 33 (2), 150-164. https://doi.org/10.1177\%2F000765039403300202

Frederick, W.C. (1986). Toward CSR3: Why Ethical Analysis is Indispensable and Unavoidable in Corporate Affairs, California Management Review, 28 (2), 126-141. https://doi.org/10.2307\%2F41165190

Frederick, W.C. (1960). The Growing Concern over Business Responsibility, California Management Review, 2 (4), 54-61. https://doi.org/10.2307\%2F41165405

Freeman, R.E., \& Dmytriyev, S. (2017). Corporate Social Responsibility and Stakeholder Theory: Learning From Each Other, Symphonya. Emerging Issues in Management (symphonya.unimib.it), (2), 7-5. http://dx.doi.org/10.4468/2017.1.02freeman.dmytriyev

Freeman E. (2010). Strategic Management: A Stakeholder Approach, Cambridge University Press.

Freeman E. (1984). Strategic Management: A Stakeholder Approach, Cambridge University Press.

García-Sánchez, I.M., \& Noguera-Gámez, L. (2017). Integrated Reporting and Stakeholder Engagement: The Effect on Information Asymmetry, Corporate Social Responsibility and Environmental Management, 24 (5), 395-413. https://doi.org/10.1002/csr.1415

Gnecchi, F. (2009). Market-Driven Management, Market Space and Value Proposition, Symphonya. Emerging Issues in Management (symphonya.unimib.it), (2), 33-45. http://dx.doi.org/10.4468/2009.2.04gnecchi

Heald, M. (1957). Management's Responsibility to Society: The Growth of an Idea, The Business History Review, 31 (4), 375-384. https://doi.org/10.2307/3111413

Henderson, H., (1968). Should Business Tackle Society’s Problems?, Harvard Business Review, 46 (4), 77-85.

Henriques, A., \& Richardson, J. (eds.) (2004). The Triple Bottom Line: Does it All Add Up?, London: Earthscan.

Javalgi, R., \& Ramsey, R. (2001). Strategic Issues of E-Commerce as an Alternative Global Distribution System, International Marketing Review, 18 (4), 376-391. https://doi.org/10.1108/02651330110398387

Johnson, H.L. (1971). Business in Contemporary Society: Framework and Issues, Belmont, CA: Wadsworth.

Jones T. (1980). Corporate Social Responsibility Revisited, Redefined, California Management Review, 22 (3), 59-67. https://doi.org/10.2307/41164877

Keijzers, G. (2002). The Transition to the Sustainable Enterprise, Journal of Cleaner Production, 10 (4), 349-359. doi: 10.1016/S0959-6526(01)00051-8 
McGuire, J.W. (1963). Business and Society, New York: McGraw-Hill.

Perrini, F., Pogutz, S. \& Tencati, A. (2006a). Corporate Social Responsibility in Italy: State of Art, Journal of Business Strategies, 23 (1), 65-91.

Perrini, F., Pogutz, S. \& Tencati, A. (2006b). Developing Corporate Social Responsibility. A European Perspective, Cheltenham: Edward Elgar.

Riboldazzi, S. (2016). Corporate Governance and Sustainability in Italian Large-Scale Retail Companies, European Scientific Journal, 12 (16), 1-23. doi: 10.19044/esj.2016.v12n16p1

Riboldazzi, S. (2015). Global Markets and Development Policies in Large-Scale Retailers, Symphonya. Emerging Issues in Management (symphonya.unimib.it), (5), 8-28. http://dx.doi.org/10.4468/2015.5.02riboldazzi

Riboldazzi, S. (2010). Retail Policies in the Global Gasoline Market, Symphonya. Emerging Issues in Management (symphonya.unimib.it), 86-101. http://dx.doi.org/10.4468/2010.1.09riboldazzi

Riboldazzi, S. (2005). Global Retailers and Competitive Customer Value, Symphonya. Emerging $\begin{array}{llll}\text { Issue in } \quad \text { Management } & \text { (symphonya.unimib.it), }\end{array}$ http://dx.doi.org/10.4468/2005.2.07riboldazzi

Risso, M. (2010). Large Retailers' Financial Services, Symphonya. Emerging Issues in Management (symphonya.unimib.it), (1), 65-75. http://dx.doi.org/10.4468/2010.1.07risso

Salvioni, D.M. (2003). Corporate Governance and Global Responsibility, Symphonya. Emerging Issues in Management (www.unimib.it/symphonya), (1), 44-54. http://dx.doi.org/10.4468/2003.1.05salvioni

Salvioni, D.M., \& Gennari, F. (2017). CSR, Sustainable Value Creation and Shareholder Relations, Symphonya. Emerging Issues in Management (symphonya.unimib.it), (1), 36-49. http://dx.doi.org/10.4468/2017.1.04salvioni.gennari

Sethi, S.P., (1975). Dimensions of Corporate Social Performance: An Analytical Framework, California Management Review, 17 (3), 58-64. https://doi.org/10.2307\%2F41162149

Steiner G. (1971). Business and Society, New York: Random House.

Wiese, A., Kellner, J., Lietke, B., \& Toporowski, W. (2012). Sustainability in Retailing - a Summative Content Analysis, International Journal of Retail \& Distribution Management, 40 (4), 318-335. https://doi.org/10.1108/09590551211211792 